\title{
Should Australia Introduce a Prohibition on Unfair Trading? Responding to Exploitative Business Systems in Person and Online
}

\author{
J. M. Paterson ${ }^{1}$ (D) E. Bant ${ }^{2}$ \\ Received: 10 March 2020 / Accepted: 16 July 2020/ Published online: 22 August 2020 \\ (C) Springer Science+Business Media, LLC, part of Springer Nature 2020
}

\begin{abstract}
Australian consumer protection law contains broad and flexible prohibitions on misleading and unconscionable conduct in trade or commerce. Yet concerns have been raised that these prohibitions are unsuitable for responding to predatory business systems. These are businesses that, by design or operation, target consumers experiencing vulnerability to offer costly products ill-suited to their needs. This concern has arisen in response to prominent instances of products of dubious efficacy offered to marginalized communities. It has also arisen from concerns over the increasing potential for data-driven digital marketing to manipulate consumer choice by targeting with fine-grained accuracy consumer vulnerabilities. In response to these concerns, it has been suggested that the Australian Consumer Law should be reformed, by introducing a prohibition on "unfair trading" inspired by the general prohibitions on such conduct in the EU and USA. This paper explores the key considerations relevant in assessing the merits of this proposed statutory "transplant." Ultimately, the paper is supportive of the proposed reform, while also recognizing its limits.
\end{abstract}

Keywords Unfair commercial practices · Unfair trading · Unconscionable conduct · Unfair business systems $\cdot$ Disadvantaged communities $\cdot$ Digital manipulation $\cdot$ Regulatory design

Australian consumer protection law is replete with principles-based prohibitions on conduct that offends community values and disrupts the fair and efficient operation of the market. In

This article is part of an Australian Research Council funded project DP180100932 on coherence in the general prohibition on misleading conduct in the Australian Consumer Law. Research assistance provided by Yi Tung and Calvin Collins, JD Candidates, Melbourne Law School. Errors are our own.

\section{J. M. Paterson}

jeanniep@unimelb.edu.au

E. Bant

elise.bant@uwa.edu.au

1 Melbourne Law School, The University of Melbourne, Melbourne, Australia

2 Law School, University of Western Australia, Perth, Australia 
particular, the key statutory regime, the Australian Consumer Law (ACL), contains opentextured prohibitions on misleading and unconscionable conduct in "trade or commerce" ( $A C L$, Section 18 and Sections 21 and 22), as well as regulatory powers to respond to unfair contract terms (ACL, Parts 2-3). These prohibitions are accompanied by a swathe of specific rules governing particular kinds of conduct thought to be prejudicial to consumers. It has nonetheless been suggested that the $A C L$ should be amended to introduce a prohibition on "unfair trading" based on the general prohibitions in the European Union's Directive on Unfair Commercial Practices (Directive 2005/29/EC) Article 5 or the United States' Federal Trade Commission Act 1914 Section 45 (CAANZ 2017, pp. 91, 96; ACCC 2019, p. 26). The suggestion for reform arises from concerns that the existing prohibition on unconscionable conduct has proven incapable of responding to business systems that target consumers who are experiencing vulnerability with costly products unsuitable for their needs, as opposed to responding to individual instances of transactional advantage-taking (Paterson and Brody 2015). Interest in a prohibition on unfair trading has also been prompted by concerns that the current regime may not provide an adequate response to the potential for new data collection practices and predictive analytics informing digital marketing strategies to manipulate and distort consumer choice (ACCC 2019, p. 26).

We are generally supportive of the proposal to introduce a prohibition on unfair trading in Australian consumer law. In principle, we think that a prohibition on unfair trading may resonate better with the modern realities of business systems or practices that are predatory by reason of their very design or operation than the prohibition on unconscionable conduct. Despite repeated statutory reform, the statutory prohibition on unconscionable conduct has, in our opinion, struggled to free itself from its equitable origins. In this regard, the transplant may prompt courts to address conduct harmful to consumers that is not captured by the existing regime. We also consider it is important not to overestimate the capacity of any new prohibition to resolve all of the problems prompting its adoption. Transplants rarely develop precisely in the way utilized in the origin regime or even necessarily as expected in the new regime (Teubner 1998). Moreover, our observation is that neither of the proposed models for reform has been used squarely to address the problems with which we are concerned. Partly this is because the prohibitions on unfair trading in the Europian Union Directive (EU Directive) and United States (US) Federal Trade Commission Act are, like the existing prohibition on unconscionable conduct in the $A C L$, "safety net" provisions that respond to harmful conduct not addressed by more specific rules (see also Paterson and Brody 2015). In addition, the concerns over the impact of digital technologies driving the call for reform are relatively recent ones that many jurisdictions are only beginning to address, Australia notably lagging behind the EU in this regard. Nonetheless, we consider that a coordinated and careful reform process has potential to develop proactive and useful responses to the issues of concern.

In this article, we explore the considerations relevant to the proposal that Australia adopt a prohibition on unfair trading. While this analysis has considerable obvious relevance to Australia, its observations on the transplant of parts of a consumer protection regime to a new jurisdiction, will be of interest beyond this specific test case. It is likely that many jurisdictions will increasingly be confronted with business systems that are unfair in the sense we discuss in this article, particularly given the opportunities for the manipulation of consumer vulnerabilities enabled by new digital technologies.

We begin by briefly considering the role of transplants in consumer protection law, noting that the $A C L$ contains many provisions that have been "transplanted" from afar. We then turn to the existing Australian prohibition on unconscionable conduct. We address the limitations on the operation of that prohibition in responding to harmful business systems that have led to renewed calls for reform, noting in particular uncertainty about the standard used to assess a 
contravention and the issues with the evidence and case theory presented by regulators. We note the continued uncertainty about the meaning of unconscionable conduct and suggest that, in that light, a prohibition on unfair trading may be more effective. We then turn to the two proposed models for reform from the EU and US and consider their potential for addressing business systems that are, by their very design or method of operation, exploitive. Finally, we consider the potential for data-driven applications of digital marketing to target consumer vulnerabilities and manipulate consumer choice, as raised by the Australian Competition and Consumer Commission (ACCC) in its Digital Platforms Inquiry Report of 2019.

\section{Transplants in Australian Consumer Law}

The suggestion to introduce an unfair trading prohibition in Australia envisages transplanting a statutory prohibition from either the EU or the USA. Borrowing consumer protection provisions from another jurisdiction is not a new phenomenon in Australian law. The key prohibitions in the $A C L$ on misleading and unconscionable conduct were influenced, respectively, by Section 5 of the US Federal Trade Commission Act and Section 2-302 of the Uniform Commercial Code 1952 (Queensland University of Technology 2016 [2.2]; Duggan 1996, p. 995). The Australian regime rendering void unfair terms in standard form consumer contracts (ACL Parts 2-3) is closely modelled on the EU Directive on Unfair Terms in Consumer Contracts (Council Directive 93/13, 1993 OJ L95/29), with some adaptions to fit local conditions (Paterson 2009). The consumer guarantee regime, replacing implied terms of fitness and quality, was borrowed from New Zealand (Paterson 2011).

There are different views about how the efficacy of a law transplanted from one jurisdiction to another should be assessed (e.g., Graziadei 2006; Legrand 1997). Teubner and Chen-Wishart make the point that the issue is not most usefully framed in terms of a binary opposition between an effective and a rejected reception (Teubner 1998, p. 12; Chen-Wishart 2013, p. 3). In most cases, the key question is not whether the transplanted law "works" but the ways in which the transplant is transformed by and adapted to local conditions. Teubner famously described this process in terms of "irritants." The introduction of a foreign law will trigger changes within the jurisdiction into which it is received as well as itself being reconstructed by the operation of that new legal environment. This means the new law will, of necessarily, operate differently from the jurisdiction from which it came (Teubner 1998, p. 13). The effect of the transplanted law will therefore depend very much on the context into which it arrives and its effects must be studied on a case-by-case basis (Chen-Wishart 2013, p. 3).

Often these issues are explored in connection with transfers between civilian and common law jurisdictions (cf., Himsworth 2019) and, in the case of common law jurisdictions, on judge-made as opposed to statutory law (also Hill 2020; Giliker 2017). Nonetheless, the same insights seem likely to apply to the transplant of statutory schemes. Statute operates within the context of a number of influential legal factors, including the surrounding statutory landscape, judge-made law, and judicial approaches to interpretation, which will strongly influence the reception of the regime (Paterson et al. 2019). Where, as in the case of consumer protection law, the transplant is targeted at addressing particular consumer harms, the common experience of that harm across jurisdictions might be sufficient to ensure the relatively smooth reception of the transplant. For example, similar kinds of terms have been challenged under unfair contract term regimes in the EU Directive on Unfair Contract Terms and Parts 2-3 of the $A C L$ (Paterson 2019a). 
Yet equally, the approach to transplants made to address consumer protection concerns across jurisdictions must necessarily be influenced by national attitudes towards the degree to which market interactions should be regulated and the kinds of consumer attributes that should be protected by the law. In the case of the proposal to adopt a prohibition on unfair trading in Australian consumer protection law, we may see both kinds of forces at play. The purpose stems from a response to particularly local circumstances and also to the influence exercised by digital platforms that transcends national boundaries. The operation of legal transplants will also be influenced by the extent to which the concepts deployed by the new provisions already have a meaning within the receiving body of law. In the case of Australia, the reasons for adopting a prohibition on unfair trading comes close to a deliberate use of Teubner's concept of an irritant (Teubner 1998). At the least, it may serve to prompt Australian courts to go beyond existing approaches in responding to systemically predatory business models and the growing influence of manipulative methods of online digital marketing.

\section{The Existing Prohibition on Unconscionable Conduct in the Australian Consumer Law}

Prohibitions on unconscionable conduct have been part of the Australian consumer protection regime since 1986 and have been subject to reform ever since. There are now two sets of provisions that address unconscionable conduct in the ACL (Sharpe 2018; Paterson 2019b, Chapter 4). The precursor to Section 20 was introduced in 1992 to prohibit unconscionable conduct "within the meaning of the unwritten law." The prohibition provides access to statutory remedies in response to conduct that contravenes equitable doctrines based on unconscionability, primarily the wrong of unconscionable dealing. The key element of this equitable wrong is that a defendant takes unconscionable advantage of a plaintiff's circumstances of special disadvantage (Thorne v Kennedy 2017). Section 20 does not apply where Section 21 is applicable, and so its scope is now very limited, ${ }^{1}$ although as we shall see the influence of the equitable concept of unconscionable dealing remain strong in interpreting Section 21.

Section 21 of the $A C L$ contains a broader prohibition, with which this article is chiefly concerned. In its current form, Section 21 prohibits conduct "in trade or commerce," that is, "in all the circumstances," "unconscionable." of interpretative principles to guide courts in their application of the prohibition. These interpretative principles have confirmed that this statutory prohibition on unconscionable conduct is not confined by the doctrine of unconscionable dealing developed in equity (ACL, Section 21(4)(a)). Importantly, the principles also confirm that the "section is capable of applying to a system of conduct or pattern of behaviour, whether or not a particular individual is identified as having been disadvantaged by the conduct or behaviour" ( $A C L$, Section 21(4)(b)). ${ }^{3}$ Section 21 is augmented by Section 22, which contains a list of factors to which the court may have regard in deciding if conduct is unconscionable contrary to the

\footnotetext{
${ }^{1}$ Until 2018, the protection in Section 21 did not apply a listed public company, and hence, Section 20 was applicable in this context. This restriction on the scope of Section 21 was removed by the Treasury Laws Amendment (Australian Consumer Law Review) Act 2018.

${ }^{2}$ An equivalent prohibition applying to financial services exists in the Australian Securities and Investment Commission Act 2009 (Cth) Section 12CB.

${ }^{3}$ Both of these principles had also been recognized in earlier decisions of the courts (Australian Securities and Investments Commission v National Exchange Pty Ltd (2005) (National Exchange), p. 140 [30]).
} 
statute. This is required because, while clearly intended to be distinct from the equitable doctrine of unconscionable dealing, the standard of behaviour prohibited by Section 21 is undefined. The factors are not a checklist for establishing unconscionable conduct (National Exchange (2005) [40]). The factors contain a mix of substantive and procedural considerations consistent with what has been termed the "sliding scale" of unconscionability where the Court weighs up the combined effect of all of the factors of the case (Lonegrass 2012-2013).

Despite this history of reform, the Consumer Affairs Australia and New Zealand Review of the $A C L$ in 2017 (CAANZ 2017, p. 96) and before that the Productivity Commission in 2008 (Productivity Commission 2008 [7.2]) raised the possibility of introducing a prohibition on unfair trading in the $A C L$ to respond to "market-wide or systemic 'predatory' practices." The case for reform has been given a new impetus by concerns over a number of recent cases in which Australian courts dismissed the regulators' arguments that a business system was unconscionable in preying upon disadvantaged communities (e.g., Unique International College Pty Ltd $v$ Australian Competition and Consumer Commission (2018) (Unique College); Australian Securities and Investments Commission v Kobelt (2019) (Kobelt). As a consequence, the proposal has attracted the support of some members of the judiciary and consumer advocates (e.g., Kobelt 2019 [311]; Butler 2019; Brody and Temple 2016). Additionally, the ACCC's far reaching Digital Platform Inquiry Report recommended considering the introduction of an unfair trading prohibition as part of a suite of reforms to provide better protection to consumers in data-driven markets (ACCC 2019, p. 26). The concerns about the adequacy of the prohibition on unconscionable conduct in these contexts arise primarily from uncertainty about its meaning and its adequacy for addressing systematic misconduct.

\section{The Standard for Assessing Unconscionable Conduct}

The meaning and operation of the prohibition in Section 21 of the ACL have always been contentious (Duggan 1991; Bathurst 2020). The quest to identify the guiding principles for assessing conduct that offends the statutory prohibition remains ongoing, with different views on the proper standard being expressed in the courts. One kind of "holistic" approach sees the statutory prohibition on unconscionable conduct as expressing a general condemnation of "sharp practice" contrary to community norms without placing undue weight on any particular linguistic descriptor (see, e.g., Paciocco v Australia and New Zealand Banking Group Ltd 2015 at 274 [296], cited with approval in Kobelt (2019) [14]). Thus, the prohibition on unconscionable conduct is treated as capable of sanctioning conduct that may be described as unfair, unjust, or lacking in good faith notwithstanding their different linguistic forms (see, e.g., Kobelt (2019) [311] (Edelman J)). If correct, this analysis would mean that there was little additional work to be done by a prohibition on unfair trading. Harmful conduct that might be caught by such a regime should equally be addressed by the existing prohibition on unconscionable conduct.

Another school of thought takes a more formalistic approach to the interpretation of the statutory prohibition. This approach operates from the premise that the use of different words to describe the standards of prohibited conduct within one statute or in related legislation requires that different meanings should to be given to each (Kobelt (2019) [311]). Thus, some Australian courts have distinguished the standard of misconduct prohibited by unconscionable conduct from conduct that is unfair or unjust (Attorney-General (NSW) v World Best Holdings 
Ltd 2005, p. 583 [121]), ${ }^{4}$ with unconscionable conduct demanding a higher standard of wrongdoing than conduct that is merely unfair.

Which of these two approaches should be preferred remains to be conclusively settled by Australian courts. But constant wavering in the courts between the two streams of thought has created uncertainty and supports suggestions for reform. The uncertainty around ACL Section 21 was starkly illustrated by the decision of the High Court of Australia in Kobelt (2019), which although not squarely addressing the question of the proper interpretation of the Section 21 prohibition on unconscionable conduct, signals an undeniably restrictive operation of that regime.

Kobelt concerned an informal credit scheme known as "book-up" provided by Mr. Kobelt to the local Anangu community, the indigenous residents of the remote South Australian APY Lands, on which Mr. Kobelt operated a general store (for the factual background, see Australian Securities and Investments Commission v Kobelt (2016). The relevant Anangu customers of Mr. Kobelt's book-up scheme were, and remain, extremely poor with very low financial literacy and little to no access to credit or vehicles outside of the small town of Mintabie, where Mr. Kobelt ran his business. His book-up scheme allowed Anangu customers to purchase goods and second-hand motor vehicles on credit at the store operated by Kobelt. In return, Kobelt required Anangu customers to provide him with their debit cards, PINs (personal identification numbers, a password), and details of their income. Kobelt used these details to withdraw the whole of the customers' money from their bank account on or around the day they were paid. Around half of the withdrawn amount was used to pay down the debt on the second-hand motor vehicles, while the balance was permitted to be used as credit for goods, cash advances, or money orders for other stores.

The credit charges for purchasing cars were not disclosed, and the credit provided was expensive. ${ }^{5}$ It was shown that over 12- and 24-month periods, respectively, the minimum credit charge amounted to approximately $300 \%$ and $150 \%$ of the annual commercial interest rate for vendor finance on a vehicle, at rates of $43.4 \%$ and $22.4 \%$, respectively. It did not appear that the customers were aware of the credit charges. These charges were in addition to the fees charged by Mr. Kobelt for purchase orders and cash advances, the book-down cost of goods and, in particular, fuel which customers were otherwise obliged to travel to Nobby's to purchase. The customers were not provided with information about the transactions or statements of account. The records of the arrangements were unintelligible and chaotic. ${ }^{6}$

At first instance, White $\mathrm{J}$ in the Federal Court held that the system was unconscionable (Australian Securities and Investments Commission v Kobelt (2016)). The Full Federal Court ${ }^{7}$ allowed an appeal by Mr. Kobelt (Kobelt v Australian Securities and Investments Commission (2018)). By a bare majority, ${ }^{8}$ the High Court (Kobelt (2019)) dismissed an appeal from this decision to hold that Mr. Kobelt's conduct did not contravene the statutory prohibition on unconscionable conduct. In so doing, the majority drew heavily on the more restrictive

\footnotetext{
${ }^{4}$ See also on this approach: Director of Consumer Affairs Victoria v Scully (2013), p. 183 [48]; Perpetual Trustee Company Ltd v Khoshaba 2006; Tonto Home Loans Australia Pty Ltd v Tavares 2011.

${ }^{5} \mathrm{Mr}$. Kobelt was successfully prosecuted for breaches of Section 29(1) of the National Consumer Credit Protection Act 2009 (Cth), which prohibits a person from engaging in a "credit activity" if they do not have a licence authorizing them to engage in that activity.

${ }^{6}$ Receipts from Mr. Kobelt's withdrawals would be stored in plastic bags until full, usually discarded after two to three months. Mr. Kobelt kept a diary in relation to book-up transactions, but its entries were difficult even for the Court's forensic accountant to understand: Kobelt (2019), at [31]).

${ }^{7}$ Besanko and Gilmour JJ and Wigney J.

${ }^{8}$ Kiefel CJ and Bell J; Gageler J and Keane J agreeing; Nettle and Gordon JJ dissenting; Edelman J dissenting.
} 
equitable doctrine of unconscionable dealing to conceptualize the boundaries of unconscionable conduct under Section 21. The majority did not consider that Mr. Kobelt had taken unconscientious advantage of the disadvantaged situation of the Anangu people or their lack of education and financial literacy (Kobelt v (2019) [77], [107]). The majority judges considered that the Anangu customers had a rudimentary but adequate understanding of the basic operation of Kobelt's book-up system (Kobelt (2019) [78], [108], [129]). This meant there was an element of choice in their use of the system (Kobelt (2019) [107], [109]-[110]). The system provided a benefit to Mr. Kobelt's Anangu customers in the form of a means to purchase motor vehicles, notwithstanding their low incomes and lack of assets with which to secure a loan (Kobelt (2019) [64]-[65]). ${ }^{9}$

By contrast, the minority judges focused squarely on the inherently exploitative elements of the system operated by Mr. Kobelt (Kobelt (2019) [259]), including the requirements that:

as security for relatively modest advances, the borrower hand over the right to receive the whole of the borrower's meagre monthly income, with not less than half of it to be applied in reduction of the loan; the borrower confer on the credit provider an untrammelled discretion as to how much, if any, of the other half should be made available to the borrower for the purchase of life's necessities; and the borrower be tied to purchasing all such necessities from the credit provider at the credit provider's prices, or else pay the credit provider for the privilege of a 'purchase order.'

For the minority, if the focus was on the business model itself and the way it had been implemented, it was irrelevant that some of Kobelt's Anangu customers may have understood the rudiments of the book-up system. The position of the customers was such that they could not exercise a genuine choice nor demand a superior alternative (Kobelt (2019) [240], [313]).

We have argued elsewhere that the approach of the minority is to be strongly preferred (Paterson et al. 2019). Indeed, we suggest that the single factor of the abysmal standard of Kobelt's financial "records" should have sufficed to show that his credit "system" was inherently unconscionable. The question raised by this case, when considered in the light of proposals to reform Australian consumer law by introducing a prohibition on unfair trading, is whether the result was attributable to the way in which the case was presented and argued, as opposed to limitations in the existing prohibition on unconscionable conduct. The challenge is to understand whether addressing this practice removes the need for reform.

\section{Does the Problem Lie in the Way the Cases Have Been Argued?}

Australian courts, and indeed regulators, have at times struggled to conceptualize the character of the concern around controversial business systems (as opposed to odious individual action). These conceptual flaws have undermined a number of cases where the regulator has failed to establish unconscionable conduct in a "system of conduct or pattern of behaviour" (Unique College (2018); Kobelt (2019). We suggest that the repeated difficulty with developing a cogent, evidential "theory of the case" may reflect doctrinal confusion between different forms of "unconscionable" conduct. Under the traditional equitable doctrine of unconscionable

\footnotetext{
${ }^{9}$ In addition, the majority considered that Mr. Kobelt's book-up system provided a response to the problems of "humbugging" and "demand sharing," in indigenous communities (Kobelt (2019), [69]). See further Yates and Sharman (2019).
} 
dealing, the focus is on interpersonal transactions. The court will consider whether the plaintiff was at a special disadvantage which the defendant took advantage of or exploited (see, e.g., Australian Competition and Consumer Commission v Keshow (2005)). Here, evidence adduced by the regulator will usually (and rightly) relate to the specific traits and circumstances of the individual parties and the transaction into which they entered. Yet increasingly regulators have sought to bring a claim of statutory unconscionable conduct in response to a business system that has, or is likely to have, the effect of exploiting the target consumers. The reason for this interest in targeting business systems as opposed to individual instances of exploitative conduct is to capture business practices that are predatory by design or implementation, as opposed to being problematic in their application to an individual consumer. An example is a deliberate strategy of marketing expensive or unsuitable products to consumers who lack choice or experience in the market. The regulatory attraction in this kind of approach is that it allows the whole of the business system to be put under scrutiny, with the possibility of larger civil penalties being paid (under ACL Section 224) and the benefit of a strong, public condemnation of the business system, presumably the goal of the litigation in Kobelt (2019), ${ }^{10}$ as opposed to focus being on an unfortunate instance of an individual rogue salesperson (e.g., Australian Competition and Consumer Commission v Keshow (2005)).

These kinds of claim require a different case strategy. The focus is not on the impact on a few individual consumers but on the way in which the business practice operates. The potential for this different kind of claim was identified by the Full Federal Court in National Exchange (2005). The court considered that the original statutory unconscionable conduct was capable of applying to a system of conduct or pattern of behaviour (National Exchange (2005) [33]. The case concerned conduct of National Exchange Pty Ltd in sending unsolicited off-market offers to members of a recently demutualized company, Aevum, to buy shares at a price of $\$ 0.35$ per share. The offer document contained a statement advising the shareholders that National Exchange considered that a fair estimate of the value of each share was in the range of $\$ 0.90-1.29$. Notwithstanding this, National Exchange's offers to purchase at $\$ 0.35$ per share were accepted by 257 shareholders.

The Court did not require evidence that specific individuals had been exploited or subject to predation by National Exchange (National Exchange (2005) [44]. It was sufficient that:

National Exchange set out to systematically implement a strategy to take advantage of the fact that amongst the official members there would be a group of inexperienced persons who would act irrationally from a purely commercial viewpoint and would accept the offer. They were perceived to be vulnerable targets and ripe for exploitation, as they would be likely to act inadvertently and sell their shares without obtaining proper advice, and they were a predictable class of members from whom [National Exchange] could procure a substantial financial advantage by reason of their commercially irrational conduct. ${ }^{11}$

Section 21(4)(b) of the ACL now confirms that the prohibition is capable of applying to a system of conduct or pattern of behaviour, whether or not a particular individual is identified as the victim of that conduct or behaviour (Unique College (2018) [104]; Explanatory

\footnotetext{
${ }^{10}$ See above $\mathrm{n} 4$.

${ }^{11}$ See also Australian Competition and Consumer Commission v ACN 117372915 Pty Ltd (in liq) (formerly Advanced Medical Institute Pty Limited) [2015] FCA 368 (unconscionable system of conduct in addressing erectile dysfunction).
} 
Memorandum, Competition and Consumer Legislation Amendment Bill 2010 [2.21]). Yet, experience to date with Section 21 suggests that courts will not typically draw an inference of an unconscionable system of conduct from an assessment of the nature of the product presented. Indeed, one might have thought that the system under scrutiny in Kobelt was on par with National Exchange. The combination of lack of choice, onerous and costly terms, utterly inadequate records, and the poor quality of service provided to a patently vulnerable consumer group might have been thought to evidence a system that could only be characterized as exploitative and predatory. Instead, as explained above, the majority judges emphasized what they saw as the exercise of choice by the Anangu customers and the advantages to those people provided by the system (Kobelt (2019) [78], [108], [129]). Gageler J indicated that a different result would only have followed if it had been established that the "practical consequence" of Mr. Kobelt's book-up system was to "lock the parties in a cycle of debt" (Kobelt (2019) [103]).

Another example is Unique (2018), which concerned a private education college offering vocational training programmes. Unique received around $\$ 57 \mathrm{~m}$ from the Commonwealth Government for those student enrolments, raising a concern on the part of the regulator that its behaviour was motivated by the incentive of government payments for signing up students rather than the educational outcome of graduating students (Unique (2018), at [42]). The ACCC argued that Unique had engaged in systemic unconscionable conduct in New South Wales by targeting particular locations, including rural and remote towns, Indigenous communities, and areas with significant populations of low socio-economic status, conducting door-to-door sales and offering free laptops or iPads as an enrolment incentive, without adequate explanation of the obligations being assumed and fee structure it entailed (Unique, (2018) at [31]-[33]).

The Full Federal Court held that the ACCC had not established an unconscionable business system on the part of the education provider. The fact that the college had aimed its course at students from low socio-economic backgrounds, Indigenous Australians, people from remote and regional backgrounds, and the unemployed was not determinative as that was the very purpose of the government scheme ([182]). In addition, the ACCC had focused on the effect of the business system employed by the college on six individual students. The Court held that this evidence was insufficient because the ACCC failed to demo nstrate that the selection of these individual students had been "through a random or representative process, with the process disclosed on the evidence" ([110]). However, as cases such as National Exchange (2005) demonstrate, in establishing a system of conduct or pattern of behaviour, the focus of the action should primarily be on the structure and operations of business itself, as opposed to the experience of vulnerable consumers with that business.

Notably, in Unique (2018), the ACCC did not allege that the training college "systematically failed to ascertain whether the consumer was suited to the course" ([36]). Yet within the relevant period, only around $2.4 \%$ of enrolled students actually completed the course. We would have thought the low completion rates, combined with the lack of evidence of any proper assessment process for recruiting students from populations known to have limited experience with formal education of the kind being offered, should have been probative. Other relevant evidence might include remuneration structures, marketing tactics, any refund policies, the training given to staff, and any scripts or instructions given to them to govern the sales process. This evidential hurdle need not be insurmountable, as some recent systems cases illustrate (e.g., Australian Competition and Consumer Commission v Australian Institute of Professional Education Pty Ltd (2019) [939]). 
We do not, however, consider that merely improving understanding around what is needed to establish a system or pattern of unconscionable conduct resolves the concern about the adequacy of the prohibition on unconscionable conduct in addressing exploitative business systems. The use of a different value standard to describe the prohibited conduct, such as through prohibiting unfair trading, is likely to be more effective, given (as already discussed) the ongoing uncertainty over the applicable standard for assessing unconscionable conduct.

\section{Models for Reform}

As noted above, the two models that have been raised for the proposed prohibition on unfair trading in Australian consumer protection law are the EU Directive on Unfair Commercial Practices and the US Federal Trade Commission Act (ACCC 2019, pp. 440, 449). Article 5(1) of the Unfair Commercial Practices prohibits unfair commercial practices. Article 5(2) provides that a commercial practice will be unfair if:

(a) it is contrary to the requirements of professional diligence; and

(b) it materially distorts or is likely to materially distort the economic behaviour with regard to the product of the average consumer whom it reaches or to whom it is addressed, or of the average member of the group when a commercial practice is directed to a particular group of consumers.

The Federal Trade Commission Act 15 USC Section 45(a)(1) declares that unfair or deceptive acts or practices in or affecting commerce are unlawful. Under Section 45(n), the Commission has no authority to declare an act or practice unfair unless the act or practice:

causes or is likely to cause substantial injury to consumers which is not reasonably avoidable by consumers themselves and not outweighed by countervailing benefits to consumers or to competition.

The potential for these regimes to address the concerns driving suggestions for reform in Australia is not entirely straightforward. It would seem that regulators in both of the model jurisdictions have relied on other, more specific iterations of the general prohibition to address conduct that would, in any event, be caught under the $A C L$ prohibitions on misleading conduct or unconscionable conduct. In particular, under the EU Directive on Unfair Commercial Practices, regulators have made more use of specific prohibitions on misleading actions and omissions (Articles 6,7) and on aggressive conduct (Article 8) than on the general prohibition on unfair commercial practices (Article 5(1)). Consistently, Collins has observed that "it seems likely that the general clause will rarely be needed" (Collins 2010, p. 97). Similarly, in the US, the Federal Trade Commission has tended to rely on the prohibition on deceptive, rather than unfair, acts (Corones and Davis 2017, p. 72). However, it has been suggested that use of the fairness jurisdiction is increasing, particularly in response to concerns about data privacy (Solove and Hartzog 2014, p. 638).

As already noted, the evolution of a transplanted law will largely depend on local factors. One such factor is judicial approaches. In Australia, one attraction of a general prohibition on unfair commercial practices in Australian law would lie in prompting courts to move beyond a narrower notion of unconscionability in addressing exploitative or manipulative business systems that offend community standards. The very use of the word "unfair" in contrast to 
unconscionable should provide a clear signal of legislative intention to widen the scope of protection offered to consumers under the regime, an issue that, as discussed above, has stymied the development of a clear jurisprudence around the operation of the existing prohibition on unconscionable conduct. To this we may add the attraction of a standard that has more iterative response in modern secular Australian society. The very notion of unconscionable conduct may convey little to the average citizen (Paterson and Brody 2015). By contrast, it has been suggested that the concept of unfairness is "widely understood, being part of the every-day moral vocabulary of all Australians" (House of Representatives Standing Committee on Industry, Science and Technology (1997), Recommendation 6.1 [6.73]).

As we have already noted, the reception of a law from another jurisdiction will also be influenced by the existing structures of the receiving regime (Teubner 1998, p. 17). Here, the adoption of a fairness standard would bring the $A C L$ into line with financial services/consumer credit regimes. These include regulatory powers to respond to unjust contracts (Contracts Review Act 1980 (NSW)), conduct that is not honest (National Consumer Credit Protection Act 2009, Section 180A), and conduct by financial services licences that is not efficient, honest, and fair (Corporations Act 2001 (Cth), Section 912A; National Consumer Credit Protection Act (2009), Section 47(1)(a)). Following revelations of widespread corporate misconduct by the 2019 Royal Commission into Misconduct in the Banking, Insurance and Financial Services Industry, Australian regulators have emphasized the place of "fairness" in the standard of conduct expected of market participants (Royal Commission into Misconduct in the Banking, Superannuation and Financial Services Industries 2019, pp. 8-9; Shipton 2019). In this sense, the reform may contribute weight to a growing body of jurisprudence around fairness-based consumer protections in the Australian context. Early indicators in the financial services context are that courts may respond to this kind of standard in a way that is more open to sanctioning systematically exploitative business conduct than the prohibition on unconscionable conduct. In Australian Securities and Investments Commission v Westpac Securities Administration Limited (2019), the Full Federal Court described the element of fairness in the licencing obligation of "efficient, honest, and fair conduct" in providing financial and credit services (Corporations Act 2001 (Cth), Section 912A(1)(a)) as precluding "a degree of calculated sharpness" ([174]), conduct that was "sufficiently egregious" ([289]), "systemic sharp practice" ([290]), and behaviour that "undermined informed decision-making" by consumers ([398]). ${ }^{12}$

Lest it be thought that the only significance of a fairness standard lies in its rhetorical value, there are other attractions in the suggested models. The EU/US provisions on unfair trading depart from the $A C L$ in providing a structure for the analysis of unfairness, as opposed to a "shopping list" of considerations currently contained in Section 22. This kind of directed analysis via principles might have once been unfamiliar to Australian courts, which were traditionally more familiar with the extremes of either rules or standard-based prohibitions in Australian law. However, the novel regime which renders void unfair contract terms in Parts 2-3 of the ACL uses a similar structure and, after a slow start (see the discussion of Paciocco in Paterson and Bant 2020), Australian courts have more recently shown greater preparedness to engage with this kind of statutory test with more rigour.

There may also be benefits in a direct acknowledgement that a commercial practice may be assessed for its impact on a targeted group of consumers. We observe that the general prohibition in the Directive on Unfair Commercial Practices refers to conduct that is or is likely to distort the economic behaviour of the average consumer (Article 5). There may be

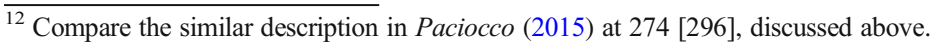


considerable merit in capturing not merely ex post but also ex ante conduct. A similar approach is already taken under the other general "safety net" provision in the $A C L$ - the prohibition on conduct that is "misleading or deceptive, or likely to mislead or deceive." The disjunctive phrase indicates that it is unnecessary to show that any person was actually misled or deceived. Instead, the statutory test necessarily requires a court to consider the objective impact of the impugned conduct, not its effect on the subjective state of mind of a particular plaintiff (Parkdale Custom Built Furniture Pty Ltd v Puxu Pty Ltd (1982), p. 198).

Including a similar phrase in any new fairness standard would expand the scope of the provision, by directing the courts' inquiry beyond specific and past interpersonal transactional abuse to considering the likely impact of the conduct on the class of persons to whom it was directed. Applying this approach to a case such as Kobelt, the question would become not whether unconscientious advantage was taken of particular plaintiffs, but whether the business system in question was likely to have a predatory or exploitative impact on the target consumer group, having regard to the identified factors for assessing contravention. It is to be hoped this question would have brought into sharp relief the problems raised by the absence of any other alternative to the book-up system for indigenous customers and the objectively substandard quality of the service provided more generally.

One risk in the model presented by the EU Directive on Unfair Commercial Practices is the invocation of a very personalized standard of appropriate conduct on the part of a trader, in assessing whether a business practice is unfair. Under Article 2(h):

'professional diligence' means the standard of special skill and care which a trader may reasonably be expected to exercise towards consumers, commensurate with honest market practice and/or the general principle of good faith in the trader's field of activity.

In Kobelt, the majority were influenced in finding that the book-up system was not unconscionable by concessions that Mr. Kobelt was acting in good faith and not dishonestly (Kobelt (2019) [60], [100]). As the minority pointed out, this should not have been relevant if the effect of his business on the indigenous consumers was unfair (Kobelt (2019) [258]). The invocation of standards of honesty and good faith may invoke personalized standards that are more applicable to individuals than corporate defendants. Personal honesty is surely irrelevant when dealing with the very specific issue of a business system or pattern of behaviour that has the impact of exploiting or preying upon particular groups of consumers, in circumstances where they cannot adequately protect their own interests. Indeed, it is these individualist notions of culpability that have arguably impeded the effectiveness of the Australian prohibition on unconscionable conduct and its civil penalties regime in responding to predatory business systems (see Paterson and Bant 2020). Willet suggests that any risk of lowering standards by reference to prevailing industry norms might be avoided through adopting the standard of good faith, "fixed by the notions of the broader community as to how trading communities should behave" (Willet 2010, p. 268). However, this meaning of good faith is highly contested in Australia (Courtney 2019; Paterson (2015), suggesting that another framework may need to be found should the EU model be favoured.

\section{Responding to Manipulative Digital Marketing Strategies}

Given the growth in digital technologies, any reform to the consumer protection regime should be designed with an eye to its effective operation in this environment. This is a particularly 
pertinent consideration in considering the regulation of predatory business systems (Zuboff 2019, also Graef et al. 2018, pp. 201-202; Zingales 2017). Increased technological capacity for data collection and predictive analytics enables business to individualize their approach to consumers through targeted advertising and differential pricing, and to vary these strategies promptly in response to granular information about consumer responses (see further Milgrom and Tadelis 2019, p. 21; Thomas 2017, p. 35; Milgrom and Tadelis 2019, p. 21; Tsesis 2019). The result is a form of digital "manipulation" or "hyper nudging," which promotes an illusion of choice where none actually exists (Calo 2014; Mik 2016; Richardson et al. 2017; Yeung 2017). The data collection and analytics now utilized by online marketing firms allows them to identify precisely the situational and constitutional vulnerabilities of consumers and to use those insights to promote amenable products, while ceasing to display other choices (Calo 2014; Clifford 2020; Helberger 2016; OECD 2017, p. 6; Vranaki 2017).

As already noted, the ACCC's Digital Platforms Inquiry Report supported proposals to consider introducing a prohibition on unfair trading in Australia, modelled on the general prohibitions in the EU or the USA. The ACCC Report saw this reform as a means of addressing detrimental practices that arise from the "significant increase in the amount of consumer data now collected and the increased sophistication in data analysis and consumer targeting" (ACCC 2019, pp. 26, 440, 499). Notably, in the home jurisdictions of the proposed models, as in Australia, these are concerns that regulators are only beginning to consider how to address (Stemler et al. 2020, p. 648). The ACCC pointed to the use of the US general prohibitions on unfair business acts to respond to discriminatory advertising and to the EU prohibition on aggressive practices to respond to conduct inducing consumers to share data (ACCC 2019, p. 440). But there has been little action as yet on the use of targeted advertising to manipulate consumer preferences. Notably, in the EU, the view has been expressed that some solely automated targeted advertising may be prohibited under Article 22 of the General Data Protection Regulation (Data Protection Working Party, Guidelines on Automated Individual Decision-Making and Profiling for the Purposes of Regulation 2016/679 2018; Kaminski 2018). This means the potential for a prohibition on unfair trading in responding to manipulative online sales strategies is as yet untested. ${ }^{13}$ Learnings from the responses provided to consumer predation in a "bricks and mortar" environment may be instructive, after all the complaint in both contexts is with business systems that systematically seek out and exploit the varied ways in which different consumers may experience vulnerability. Nonetheless, use of new digital technologies for marketing purposes raises their own regulatory challenge, not the least because of the opaqueness of the mechanisms enabling the conduct.

Blatant and extreme instances of digital marketing being used to exploit consumers on the basis of an identified vulnerability may be unconscionable in the traditional sense of interpersonal advantage-taking. For example, advertisements may be targeted at consumers who have been identified by their online conduct as experiencing some personal or emotional crisis, information which is then used to encourage consumers to sign up for products they do not need or cannot afford as a (false) way of dealing with that crisis (Bell 2019; Day 2019). By and large, however, general safety net prohibitions against unconscionable conduct may not address the core concerns over new digital marketing techniques (Mik 2016; Manwaring

\footnotetext{
${ }^{13}$ Notably, in the EU, the view has been expressed that some solely automated targeted advertising may be prohibited under article 22 of the General Data Protection Regulation: see Data Protection Working Party, Guidelines on Automated Individual Decision-Making and Profiling for the Purposes of Regualtion 2016/679, 17/En. Wp251rev.01 (Feb. 6, 2018).
} 
2018). As currently conceived, the prohibition on unconscionable conduct is aimed at conduct that blatantly pressures or exploits consumers entering into transactions (ACCC 2018). In general, the concern with the misuse of technological techniques in consumer markets is with more subtle forms of misconduct (Stemler et al. 2020).

If anything, the conduct of concern is more akin to a form of technological undue influence, in which consumers unwittingly abdicate their autonomy in decision-making to marketing algorithms. Unease with these forms of subliminal nudging or dark patterns is not that they mislead consumers or even that they impose pressure. Rather, the concern is that they persuade consumers towards certain purchasing choices, while closing off others through not making different kinds of opportunities visible in consumers' online interactions. In the Australian context, it is not impossible for that ancient equitable doctrine, which is recognized within the statutory factors indicative of unconscionable conduct under Section 22 of the $A C L$, to shed light on and protect consumers from manipulation of this kind. However, it would require the doctrine to be emancipated from its traditional context of interpersonal, trusting relationships to the new, impersonal online environment. While again, this is not impossible, the judicial innovation that would be required may be too great and too slow for effective protection from what is already an extant threat.

It is entirely possible that a prohibition on unfair trading practices might provide some response to such conduct. Here, it is noteworthy that the Directive on Unfair Commercial Practices includes a response to aggressive practices, which include the exercise of undue influence. Whether the concept extends so far as to encompass subtle pressure that comes from knowing too much about the proclivities of an individual consumer, so as to be able to manipulate their purchasing choices, or is restricted to overt pressure, remains to be seen (Willet 2010, p. 260). It is possible that the framing of the general prohibition in terms of conduct that "materially distorts" the economic behaviour of the "average consumer" may "bring in consideration of consumers' behavioural biases that might be exploited by traders" (Brody and Temple 2016, p. 164). The fairness jurisdiction under the Federal Trade Commission Act may also have the potential to address these kinds of concerns (Hirsch 2020). Here the direction in Section 45(n) to consider the risk of "substantial injury to consumers" which cannot "reasonably be avoided" may prove particularly pertinent (see Rich 2015). ${ }^{14}$

We suggest it is particularly important in this context to recognize that no single regulatory response is likely to be able to address all of these concerns about the manipulation of consumer consent through digital marketing. What is needed online, as elsewhere, is a layered regulatory regime, in which bright line rules are supplemented by more general standard-based safety net protections (Paterson 2019b, Chapter 1). Regulatory focus on strengthening consumers' rights over their data will go some way to limiting intrusive online marketing applications by restricting the flow of data which "feeds" the new predictive (and potentially predatory) technologies. Consistently, the ACCC's Digital Platforms Inquiry Report (2019) (p. 24) recommended reform of the Privacy Act 1998 (Cth) to provide for requirements for data collection and processing that mirror those in the General Data Protection Regulation

\footnotetext{
${ }^{14}$ This power has been used in response to harmful privacy practices, see Jessica Rich (Director, Bureau of Consumer Protection FTC), "Built to last: Section 5 and the changing marketplace," speech delivered at Section 5 Symposium Washington, D.C., February 26, 2015 discussing Craig Brittain, File No. 132-3120 (F.T.C. January 29, 2015) (proposed consent), available at http://www.ftc.gov/enforcement/cases-proceedings/132-3120 /craig-brittain-matter and FTC v. Sitesearch Corp. d/b/a LeapLab (D. Az. filed Dec. 23, 2014), available at http://www.ftc.gov/enforcement/cases-proceedings/142-3192/sitesearch-corporation-doing-business-leaplab.
} 
(EU) (2016). The ACCC noted that the existing regime regulating unfair terms in standard form consumer contracts may further provide some control over one-sided data collection and privacy policies and recommended heavier penalties for this kind of conduct. ${ }^{15}$

Nonetheless, stronger data rights and privacy protection in Australia on their own are unlikely to be sufficient to resolve concerns about digital marketing and other uses of consumer data (Clifford and Paterson 2020; Hirsch 2020, p. 442). Even with greater opportunities to choose whether to consent to such practices, consumers will still need substantive protections to combat fatigue and misunderstanding in data collection requests and policies. To this end, the ACCC's Digital Platforms Inquiry Report 2019 signalled that the regulator was prepared to pursue practices that depart from the expectations created by privacy provisions in contracts for online services using the existing prohibition on misleading conduct (ACCC 2019, p. 501). Litigation has been commenced against Google on this ground (ACCC 2019 and 2020). Similarly, the US Federal Trade Commission has used its powers over deceptive practices to address traders who depart from their own representations about how they will use consumer data (Solove and Hartzog 2014; Stemler et al. 2020, p. 649).

Here, lessons from the EU Directive on Unfair Commercial Practices may be useful. The ACCC has failed to establish misleading conduct contrary to the statutory prohibition in a series of cases in which the key complaint was that the trader failed to disclose critical information (Australian Competition and Consumer Commission v LG Electronics Australia Pty Ltd (2019); Director of Consumer Affairs Victoria v Good Guys Discount Warehouses (Australia) Pty Ltd (2016); Australian Competition and Consumer Commission v Medibank Private Ltd (2018)). The circumstances in which silence may mislead are unclear in Australian law (Paterson 2019b, Chapter 3). By contrast, the Directive on Unfair Commercial Practices (Article 7) clarifies the circumstances in which an omission may be misleading (Willett 2010, pp. 254-255):

A commercial practice shall be regarded as misleading if, in its factual context, taking account of all its features and circumstances and the limitations of the communication medium, it omits material information that the average consumer needs, according to the context, to take an informed transactional decision.

This form of express direction might be useful in the Australian context, prompting courts to consider directly the possibility that consumers may be misled by a failure to reveal material information to consumers.

\section{Conclusion}

The problem of business systems that systematically target consumers who are experiencing vulnerability to sell them products unsuited to their needs or budget has led to suggestions for Australian consumer protection law to adopt an unfair trading prohibition modelled on the general prohibitions in the EU's Directive on Unfair Commercial Practices or the US' Federal Trade Commission Act. We have suggested that there are considerable potential attractions in

\footnotetext{
${ }^{15}$ It should be noted that the application of this regime to data collection notices is not straightforward in Australia as some such provisions may not be "contracts" to which the regime can apply (see Clifford and Paterson 2020). A reform to extend the regime of unfair terms to notices as has occurred in the United Kingdom may also be warranted in Australia: see Consumer Rights Act 2015 (c 15) (UK) Section 61(4).
} 
such a reform in the particular Australian context. One of these attractions is in prompting Australian courts to move beyond restrictive understandings of unconscionable conduct grounded in equity to address new, systematic forms of market misconduct. Another potential strength is in responding to the use of new methods of data collection and predictive analytics in digital marketing to influence consumer choice in online forums. We have also noted the need not to overreach in promoting the relief that may be provided by the proposed reform. Safety net consumer protection provisions of the kind being contemplated always operate to support more specific forms of regulation, including giving consumers stronger rights of control over their data, with Australia lagging considerably behind the EU in this regard. This insight highlights the need for good legislative design to recognize the inherent limits of existing methods deployed to meet new forms of harmful market conduct, and also the force of complementary statutory initiatives.

More generally, we have observed the ongoing pattern of transplanting consumer protection law from other jurisdictions into Australian law. The operation of a received law in responding to the issues of concern prompting its adoption will always be dependent on the context in which it arrives, including accompanying legal regimes, current regulatory focuses and the attitudes of courts to statutory interpretation and consumer protection themes. Australia has specific doctrinal hurdles in regulating exploitative business systems that have been illustrated in recent case law. At the same time, many of the challenges for consumer protection are increasingly a global phenomenon, encouraged by the growth in digital services as a central consumable and the exponential increase in the reach of the digital platforms providing or hosting those services. These trends support the potential for productive transplanting of consumer protection laws while also highlighting the need to allow for region-specific interpretation and implementation of those statutory responses. These are lessons that may be relevant to many jurisdictions in the coming years.

\section{References}

Journals

ACCC. (2019). Digital platforms inquiry: Final report. Australian Competition and Consumer Commission: Consumer report. Canberra.

ACCC. (2020). Google allegedly misled consumers on collection and use of location data. Retrieved from $<$ https://www.accc.gov.au/media-release/google-allegedly-misled-consumers-on-collection-and-useoflocation-data>. Accessed 04/08/20

Brody, G., \& Temple, K. (2016). Unfair but not illegal: Are Australia's consumer protection laws allowing predatory businesses to flourish? Alternative Law Journal, 41, 161-165.

Bell, E. (2019). How ethical is it for advertisers to target your mood? The Guardian. Retrieved from $<$ https:/www.theguardian.com/media/commentisfree/2019/may/05/how-ethical-is-it-for-advertiserstotarget-your-mood>. Accessed 04/08/20

Butler, B. (2019). Not fair? Why Australian judges have been accused of failing Australian consumers. The Guardian. Retrieved from <https:/www.theguardian.com/australia-news/2019/sep/08/not-fair-whyjudgeshave-been-accused-of-failing-australian-consumers $>$. Accessed 04/08/20

Bathurst, T. F. (2020). Law as a reflection of the "moral conscience" of society. Opening of Law Term Address (5 February 2020).

Calo, R. (2014). Digital market manipulation. George Washington Law Review, 82, 995-1051.

Chen-Wishart, M. (2013). Legal transplant of undue influence. International Comparative Law Quarterly, 62, 130 .

Clifford, D., \& Paterson, J. M. (2020). Consumer privacy and consent: Reform in the light of contract and consumer protection law. Australian Law Journal forthcoming. 
Collins, H. (2010). Harmonisation by example: European laws against unfair commercial practices. Modern Law Review, 73, 89-118.

Corones, S., \& Davis, J. (2017). Protecting consumer privacy and data security: Regulatory challenges and potential future directions. Federal Law Review, 45, 65-96.

Courtney, W. (2019). Good faith and termination: The English and Australian experience. Journal of Commonwealth Law, 1, 185-226.

Clifford, D. (2020). Citizen-consumers in a personalised galaxy: Emotion influenced decision-making, a true path to the dark side? In L. Edwards, B. Shaffer, \& E. Harbinja (Eds.), Future law: Emerging technology, regulation and ethics (forthcoming).

CAANZ. (2017). Australian Consumer Law review final report. Consumer Affairs Australia and New Zealand: Policy Report. Australia.

Data Protection Working Party, Guidelines on Automated Individual Decision-Making and Profiling for the Purposes of Regulation 2016/679, 17/En. Wp 251rev.01 (Feb. 6, 2018).

Duggan, A. J. (1991). Some reflections on consumer protection and the law reform process. Monash University Law Review, 17, 252-284.

Duggan, A. J. (1996). UCC influences on the development of Australian commercial law. Loyola of Los Angeles Law Review, 29, 991-1020.

Duggan, A. J. (1997). Saying nothing with words. Journal of Consumer Policy, 20, 69.

Day, M. (2019). Amazon is working on a device that can read human emotions. Bloomberg. Retrieved from $<$ https:/www.bloomberg.com/news/articles/2019-05-23/amazon-is-working-on-a-wearable-devicethatreads-human-emotions $>$. Accessed 04/08/20

Giliker, P. (2017). The consumer rights act 2015 - A bastion of European consumer rights? Legal Studies, 37, $78-102$.

Graef, I., Clifford, D., \& Valcke, P. (2018). Fairness and enforcement: Bridging competition, data protection and consumer law. International Data Privacy Law, 8, 200-223.

Graziadei, M. (2006). Comparative law as the study of transplants and receptions. In M. Reimann \& R. Zimmerman (Eds.), The Oxford handbook of comparative law (pp. 442-474). Oxford: Oxford University Press.

Hill, J. G. (2020). Shifting contours of directors' fiduciary duties and norms in comparative corporate governance. UC Irvine Journal of International, Transnational, and Comparative Law, 5, 163-183.

Himsworth, C. (2019). Transplanting irrationality from public to private law: Braganza v BP Shipping Ltd. Edinburgh Law Review, 23, 1-21.

Hirsch, D. D. (2020). From individual control to social protection: New paradigms for privacy law in the age of predictive analytics. Maryland Law Review, 79, 439-505.

Helberger, N. (2016). Profiling and targeting consumers in the internet of things - A new challenge for consumer law. In R. Schulze \& D. Staudenmayer (Eds.), Digital revolution: Challenges for contract law in practice. Oxford: Hart Publishing.

House of Representatives Standing Committee on Industry. (1997). Science and Technology. Parliament of Australia: Finding a balance - Towards fair trading in Australia. Commonwealth of Australia.

Kaminski, M. (2018). The right to explanation, explained. Berkeley Technology Law Journal, 5, 189-218.

Legrand, P. (1997). The impossibility of legal transplants. Maastricht Journal of European and Comparative Law, 4, 111-124.

Lonegrass, M. T. (2012-2013). Finding room for fairness in formalism - The sliding scale approach to unconscionability. Loyola University Chicago Law Journal, 44, 1.

Manwaring, K. (2018). Will emerging information technologies outpace consumer protection law? — The case of digital consumer manipulation. Competition and Consumer Law Journal, 26, 141-181.

Mik, E. (2016). The erosion of autonomy in online consumer transactions. Law, Innovation and Technology, 8, 1-38.

Milgrom, P. R., \& Tadelis, S. (2019). How artificial intelligence and machine learning can impact market design. In A. Agrawal, J. Gans, \& A. Goldfarb (Eds.), The economics of artificial intelligence: An agenda (pp. 567585). Chicago, IL: University of Chicago Press.

OECD. (2017). Algorithms and collusion: Background note by the Secretariat. Paris: OECD Publishing.

Paterson, J. M. (2009). The Australian unfair contract terms law: The rise of substantive unfairness as a ground for review of standard form consumer contracts. Melbourne University Law Review, 33, 934-956.

Paterson, J. M. (2011). The new consumer guarantee law and the reasons for replacing the regime of statutory implied terms in consumer transactions. Melbourne University Law Review, 35, 252-279.

Paterson, J. M. (2015). Good faith duties in contract performance. Oxford Commonwealth Law Journal, 14, $283-309$.

Paterson, J. M., \& Brody, G. (2015). "Safety net" consumer protection: Using prohibitions on unfair and unconscionable conduct to respond to predatory business models. Journal of Consumer Policy, 38, 331-355.

Paterson, J. M., Bant, E., \& Clare, M. (2019). Doctrine, policy, culture and choice in assessing unconscionable conduct under statute: ASIC v Kobelt. Journal of Equity, 13, 81-112. 
Paterson, J. M. (2019a). Regulating consumer contracts in ASEAN: Variation and change. In L. Nottage, J. Malbon, J. M. Paterson, \& C. Beaton-Wells (Eds.), ASEAN consumer law harmonisation and cooperation: Achievements and challenges (pp. 205-260). Cambridge: Cambridge University Press.

Paterson, J. M. (2019b). Corones' Australian consumer law. Pyrmont: Thomson Reuters.

Paterson, J. M., \& Bant, E. (2020). Contract and the challenge of consumer law (forthcoming). In T. T. Arvind \& J. Steele (Eds.), Contract Law and the legislature: autonomy, expectations, and the making of legal doctrine. Oxford: Hart.

Productivity Commission, (2008). Review of Australia's Consumer Policy Framework, Inquiry Report No 45 vol 2. Queensland University of Technology. (2016). Comparative analysis of overseas consumer policy frameworks. In Commonwealth of Australia.

Richardson, M., Bosua, R., Clark, K., Webb, J., Ahmad, A., \& Maynard, S. (2017). Towards responsive regulation of the internet of things: Australian perspectives. Internet Policy Review, 6, 1-14.

Royal Commission into Misconduct in the Banking, Superannuation and Financial Services Industries. (2019). Final report. In Commonwealth of Australia.

Rich, J. (2015). Built to last: Section 5 and the changing marketplace. Section 5 Symposium Washington (29 January 2015).

Solove, D., \& Hartzog, W. (2014). The FTC and the new common law of privacy. Columbia Law Review, 114, 583-676.

Stemler, A., Perry, J. E., \& Haugh, T. (2020). The code of the platform. Georgia Law Review, 54, 605-662.

Sharpe, M. (2018). Unconscionable conduct in Australian consumer and commercial contracts. New York, NY: LexisNexis Butterworths.

Shipton, J. (2019). The fairness imperative. Conduct Regulator's Address: the AFR Banking and Wealth Summit (27 March 2019).

Teubner, G. (1998). Legal irritants: Good faith in British law or how unifying law ends up in new divergences. Modern Law Review, 61, 11-32.

Thomas, J. (2017). Programming, filtering, adblocking: Advertising and media automation. Media International Australia, 166, 34-43.

Tsesis, A. (2019). Marketplace of ideas, privacy, and the digital audience. Notre Dame Law Review, 94, 15851630 .

Vranaki, A. A. I. (2017). Regulating social networking sites: Facebook, online behavioural advertising, data protection laws and power. Rutgers Computer \& Technology Law Journal, 43, 168-211.

Willett, C. (2010). Fairness and consumer decision making under the unfair commercial practices directive. Journal of Consumer Policy, 33, 247-273.

Yates, R., \& Sharman, T. (2019). The place of cultural values, norms and practices: Assessing unconscionability in commercial transactions. Monash University Law Review, 45, 232-280.

Yeung, K. (2017). "Hypernudge": Big data as a mode of regulation by design. Information, Communication \& Society, 20, 118-136.

Zingales, N. (2017). Between a rock and two hard places: WhatsApp at the crossroad of competition, data protection and consumer law. Computer Law and Security Review, 33, 553-558.

Zuboff, S. (2019). The age of surveillance capitalism: The fight for a human future at the new frontier of power. London: Profile Books.

\section{Legislation}

\section{Australia}

Australian Consumer Law, schedule 2 of the Competition and Consumer Act. (2010). (Cth)

Contracts Review Act. (1980). (NSW)

Corporations Act 2001 (Cth)

Explanatory Memorandum, Competition and Consumer Legislation Amendment Bill. (2010). (Cth)

National Consumer Credit Protection Act 2009 (Cth)

Privacy Act. (1998). (Cth)

\section{European Union}

Unfair Commercial Practices Directive 2005/29/EC

Directive on Unfair Terms in Consumer Contracts. (1993). OJ L95/29

General Data Protection Regulation (EU). 2016/679 OJ L 127 


\section{UK}

Consumer Rights Act. (2015). (c 15) (UK)

\section{US}

Federal Trade Commission Act. (1914)

\section{Cases}

Attorney-General (NSW) v World Best Holdings Ltd. [2005] 63 NSWLR 557

Australian Competition and Consumer Commission v ACN 117372915 Pty Ltd (in liq) (formerly Advanced Medical Institute Pty Limited) [2015] FCA 368

Australian Competition and Consumer Commission v Australian Institute of Professional Education Pty Ltd (in liq) (No 3) [2019] FCA 1982

Australian Competition and Consumer Commission v Keshow [2005] FCA 558

Australian Competition and Consumer Commission v LG Electronics Australia Pty Ltd [2019] FCA 1456

Australian Competition and Consumer Commission v Medibank Private Ltd [2018] FCAFC 235

Australian Securities and Investments Commission v Kobelt [2016] FCA 1327

Australian Securities and Investments Commission v Kobelt [2019] HCA 18

Australian Securities and Investments Commission v National Exchange Pty Ltd (2005) 148 FCR 132

Australian Securities and Investments Commission v Westpac Securities Administration Limited [2019] FCAFC 187

Director of Consumer Affairs Victoria v Good Guys Discount Warehouses (Australia) Pty Ltd [2016] FCA 22

Director of Consumer Affairs Victoria v Scully [2013] VSCA 292

Kobelt v Australian Securities and Investments Commission [2018] FCAFC 18

Paciocco v Australia and New Zealand Banking Group Ltd (2015) FCAFC 50; 236 FCR 199

Parkdale Custom Built Furniture Pty Ltd v Puxu Pty Ltd [1982] 149 CLR 191

Perpetual Trustee Company Ltd v Khoshaba [2006] NSWCA 41

Thorne v Kennedy [2017] HCA 49; [2017] 263 CLR 85

Tonto Home Loans Australia Pty Ltd v Tavares [2011] NSWCA 389

Unique International College Pty Ltd v Australian Competition and Consumer Commission [2018] FCAFC 155

Publisher's Note Springer Nature remains neutral with regard to jurisdictional claims in published maps and institutional affiliations. 